\title{
Impact of salt stress on nutrient uptake and growth of cowpea
}

\author{
Prakash R. Patel ${ }^{1}$, Sushil S. Kajal ${ }^{2}$, Vinay R. Patel ${ }^{1}$, Vimal J. Pate $\left.\right|^{3^{\star}}$ and Sunil M. Khristi ${ }^{2}$ \\ ${ }^{1}$ Department of Biosciences, Sardar Patel University, Vallabh Vidyanagar, Gujarat - 388120, INDIA. \\ ${ }^{2}$ Ashok \& Rita Patel Institute of Integrated Study \& Research in Biotechnology and Allied Sciences, New Vallabh \\ Vidyanagar, Gujarat - 388121, INDIA \\ ${ }^{3}$ Krishi Vigyan Kendra (ICAR), Mangalbharti, Dist. Vadodara, Gujarat-391125 \\ * Corresponding author: \\ Received: 27 November 2009; Accepted: 16 March 2010.
}

\begin{abstract}
Soil salinity is a major limitation to crops production in many areas of the world. The present study reports the impact of salt stress on seeds germination, plant growth parameters and leaf ions accumulation in three cowpea [Vigna unguiculata (L.) Walp] Indian cultivars: Akshay-102, Gomti vu-89 and Pusa Falguni. The electrical conductivity (EC) of the soil was $0.75 \mathrm{dS} \mathrm{m}^{-1}$ and the $\mathrm{NaCl}$ treatments increased it to 2, 4, 6, 8 and $10 \mathrm{dS} \mathrm{m}^{-1}$. Germination percentage was recorded 10 days after sowing, while shoot and root dry weights were measured in 45 days old plants. Leaf ion concentrations for $\mathrm{Na}^{+}, \mathrm{K}^{+}, \mathrm{Ca}^{2+}, \mathrm{Cl}^{-}$and proline content were determined. The results showed that the germination percentage of seeds was highly affected by salinity in all cultivars in all salinity levels from 2 to $10 \mathrm{dS} \mathrm{m}^{-1}$. On the other hand, height and weight of all cultivars were less affected by the salt stress. Only at 10 $\mathrm{dS} \mathrm{m}^{-1} \mathrm{EC}$, significant reduction in plant height and root length could be found for all three cultivars. Salinity induced a significant increase in $\mathrm{Na}^{+}, \mathrm{Cl}^{-}$and proline concentrations, while reduced the accumulation of $\mathrm{K}^{+}$and $\mathrm{Ca}^{2+}$ in leaves of all the cultivars. Moreover, the tolerance difference between the cultivars was better observed at the lowest levels of salt stress, as reveled in the measurements of $\mathrm{K}^{+} / \mathrm{Na}^{+}$ratio and proline content. In conclusion, this study characterizes Akshay-102 as the most tolerant cultivar and establishes the measurements of germination capacity, $\mathrm{K}^{+} / \mathrm{Na}^{+}$ratio and proline accumulation as an important features to be explored in programs for selection and/or development of tolerant cultivars which make possible the utilization of waste saline water as well as the cultivation of vast areas of the tropical world affected by salinity.
\end{abstract}

Key words: Salt stress, germination, proline, potassium/sodium ratio

\section{INTRODUCTION}

Salinity is a wide spread environmental stress for crop plants in arid and coastal regions. The salinity of the soil and irrigated water is a problem that restricts yield on almost 40 million hectares of irrigated land, which is approximately onethird of the irrigated land on earth (Norlyn and Epstein, 1984). Due to increasing salt salinity large areas of arable land are being removed from crop production every year (Chapman, 1975, Epstein et al., 1980). Use of saline irrigation water and application of fertilizer are the main factors responsible for increasing soil salinity (Epstein et al., 1980).

Seed germination, seedling emergence, and their survival are particularly sensitive to substrate salinity (Mariko et al., 1992 and Baldwin et al., 1996). Changes in morphological and developmental stress as well as physiological and biochemical processes are some of the mechanisms adapted by plant towards stress (Zhu, 2001). Generally the growth of plant is reduced by salinity but may vary from species to 
species in their tolerance (Munns and Termaat, 1986). High levels of soil salinity can significantly inhibit seed germination and seedling growth, due to the combined effects of high osmotic potential and specific ion toxicity (Grieve and Suarez, 1997). Intolerance to salinity may result in physiological and biochemical disorders which prevent or delay germination or cause abnormal seedlings (Rehman et al., 1996; Ungar, 1996). Hence, introducing of salt tolerant plants is one of the ways to utilize the waste saline water and lands (Baccio et al., 2004).

Although extensive work has been carried out on the effects of salinity on cowpea (Vigna unguiculata L.) using $\mathrm{NaCl}$ as a source of salinity (Plaut et al., 1989; Jamal et al., 2006; Patel and Ramana Rao, 2007; Chanyou et al., 2007; Hussein et al., 2007; and Tawfik, 2008), tolerance against salinity at the germination stage is important in the establishment of cowpea in saline soils. Looking to the above fact, an investigation was undertaken to determine the effect of salinity levels on seed germination and plant growth under natural conditions as well as nutrient composition of plant leaf tissues of different cultivars.

\section{MATERIAL AND METHODS}

Three cowpea cultivars, Akshay-102, Gomti vu-89 and Pusa Falguni were grown outdoors in earthen pots containing $8 \mathrm{~kg}$ of soil. Soil used for the experiment was collected from the ploughed field of a nearby agriculture farm. The salinity of the soil used in the present study gave an electrical conductivity ( $E C$ of $0.75 \mathrm{dS} \mathrm{m}^{-1}$ ). The texture of the soil was clay loam (clay $49.3 \%$, silt $30.5 \%$ and sand $21.2 \%$ ). Different salinity

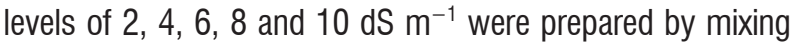
$\mathrm{NaCl}$ salt along with the soil until the soil sample measured the desired levels.

Ten seeds of each cultivar were planted in each pot. Thinning was carried out 10 days after planting, leaving four plants in each pot. The pots used during the present study had no holes at the bottom. A randomized complete block design was used with three replications. The experiment was carried out during the months of February to April 2007 and the daytime temperatures during the course of the experiment ranged from $33-45^{\circ} \mathrm{C}$.
Germination percentages were recorded 10 days after seed sowing. Shoots and roots were collected after 45 days of seed sowing and separated after cleaning the roots of soil. Fresh weights were recorded immediately after harvest and were later placed in hot air oven at $70^{\circ} \mathrm{C}$ for $24 \mathrm{~h}$ in order to determine the dry weight. Leaves were used for determination of proline content (Bates et al., 1973) and mineral composition. Ash of plant samples was prepared by heating the samples to $550^{\circ} \mathrm{C}$ in a muffle furnace for $5 \mathrm{~h}$ and was later dissolved in dilute $\mathrm{HCl}$ with a few drops of Nitric acid and was used to determine $\mathrm{Na}^{+}, \mathrm{K}^{+}$and $\mathrm{Ca}^{2+}$ using flame photometer, while $\mathrm{Cl}^{-}$contents of the leaves were determined by titration with $\mathrm{AgNO}_{3}$ (Richards, 1954). The data obtained from the various analyses and measurements were statistically analyzed using DMRT (Duncan's multiple range test) (Bliss, 1967).

\section{RESULTS AND DISCUSSION}

A comparison of the responses of the different cultivars indicated significant decrease in germination percentage with increasing salinity level. Increase in salinity from 2 to $10 \mathrm{dS} \mathrm{m}^{-1}$ drastically reduced the germination percentages from 84 to 15,82 to 10 and 64 to 6 for cowpea cv. Akshay-102, Gomti vu-89 and Pusa Falguni, respectively (Figure 1). After 45 days of sowing, plants at $10 \mathrm{dS} \mathrm{m} \mathrm{m}^{-1}$ of Akshay-102 cultivar were found to be taller than the plants of the other two cultivars. With the increase in salinity level (2 to $10 \mathrm{dS} \mathrm{m}^{-1}$ ) reduction in plant height was observed by 38,44 and $50 \%$ for Akshay102, Gomti vu-89 and Pusa Falguni, respectively (Figure 2). The results reported here are in good agreement with those reported by Bernardo et al., (2006), who observed significant reduction in seed germination, plant height and shoot dry weight with increasing salinity-induced stress in cowpea cultivars. This might be due to $\mathrm{NaCl}$ affects the permeability of the plasma membrane and increases influx of external ions and efflux of cytosolic solutes in plant cells (Allen et al., 1995). Secondly $\mathrm{NaCl}$ causes hardening of the cell wall (Nabil and Coudret, 1995) and a decrease in water conductance of the plasma membrane causing reduction in plant height (Cramer, 1992). 


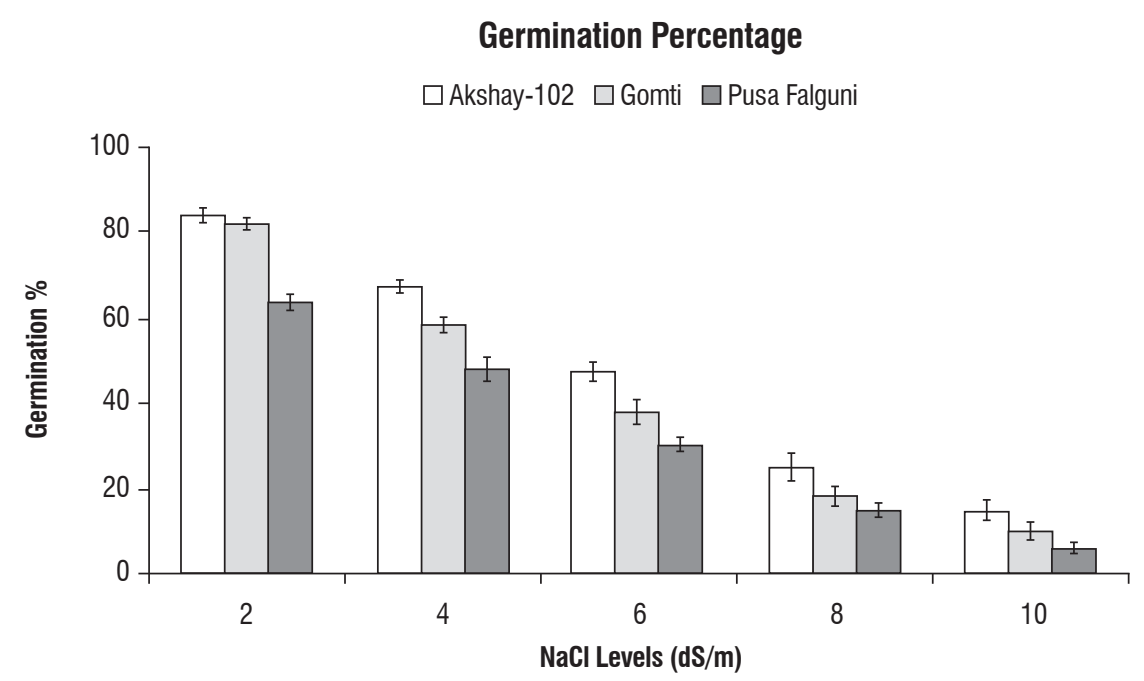

Figure 1. Effect of different $\mathrm{NaCl}$ levels $\left(2,4,6,8\right.$ and $\left.10 \mathrm{dS} \mathrm{m}^{-1}\right)$ on the germination (\%) of three cowpea cultivars after 10 days of seed sowing. (Error bar indicates \pm Standard Deviation (S. D.); $n=3 ; P<0.05)$.

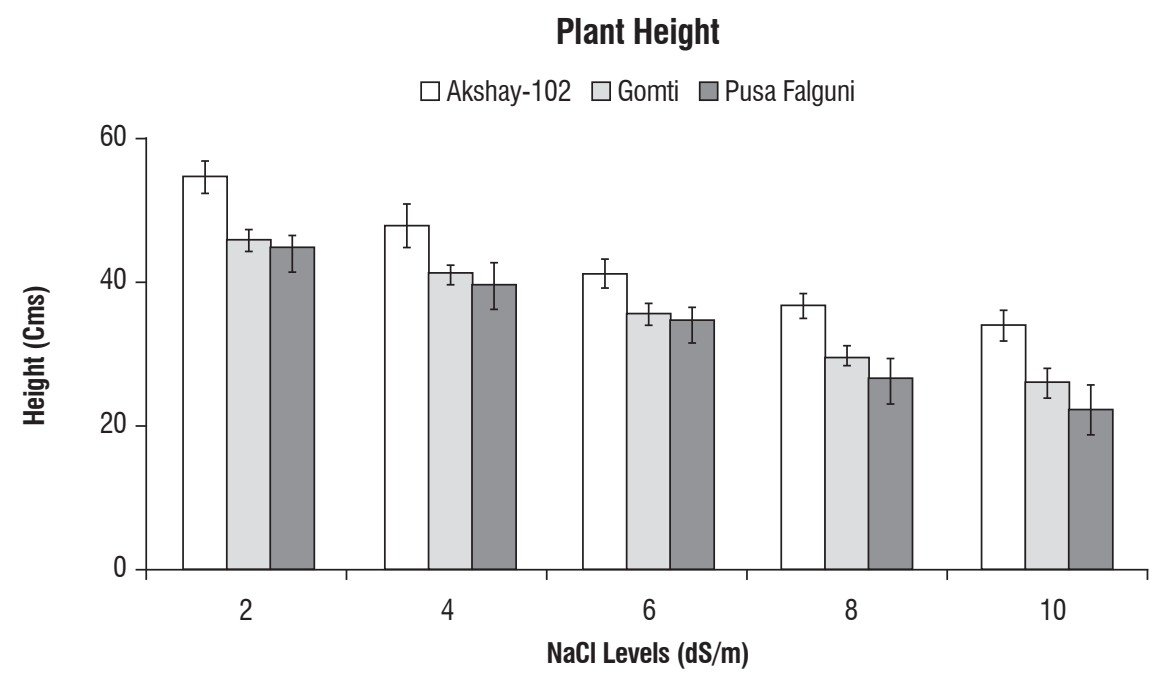

Figure 2. Variation in plant height of three cowpea cultivars after 40 days of seed sowing under different $\mathrm{NaCl}$ levels $\left(2,4,6,8\right.$ and $\left.10 \mathrm{dS} \mathrm{m} \mathrm{m}^{-1}\right)$. The data are the mean $\pm S D(n=3) ; P<0.05$.

Reduction in shoot dry weight was significantly affected with increase in salinity levels. Shoot dry weight of Akshay102, Gomti vu-89 and Pusa Falguni was reduced by 33,39 and $43 \%$ (Figure 3), while reduction of 37,44 and $53 \%$ in root dry weight was observed (Figure 4). The present results confirm that root growth was highly affected by salinity levels than shoot growth. Decrease in shoot biomass indicates an inverse relationship between salinity and biomass production (Gururaja Rao et al., 2005). 


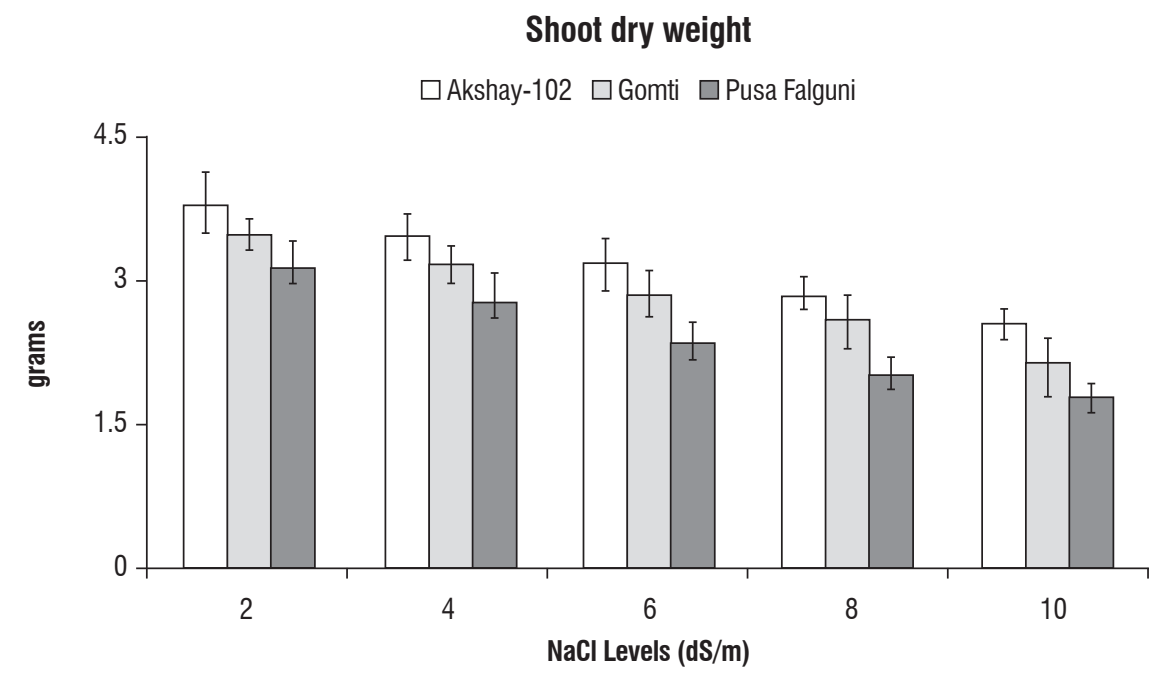

Figure 3. Variation in shoot dry weight of three cowpea cultivars under different $\mathrm{NaCl}$ levels $\left(2,4,6,8\right.$ and $\left.10 \mathrm{dS} \mathrm{m}^{-1}\right)$ after 40 days of seed sowing. The data are the mean $\pm S D(n=3) ; P<0.05$.

\section{Root dry weight}

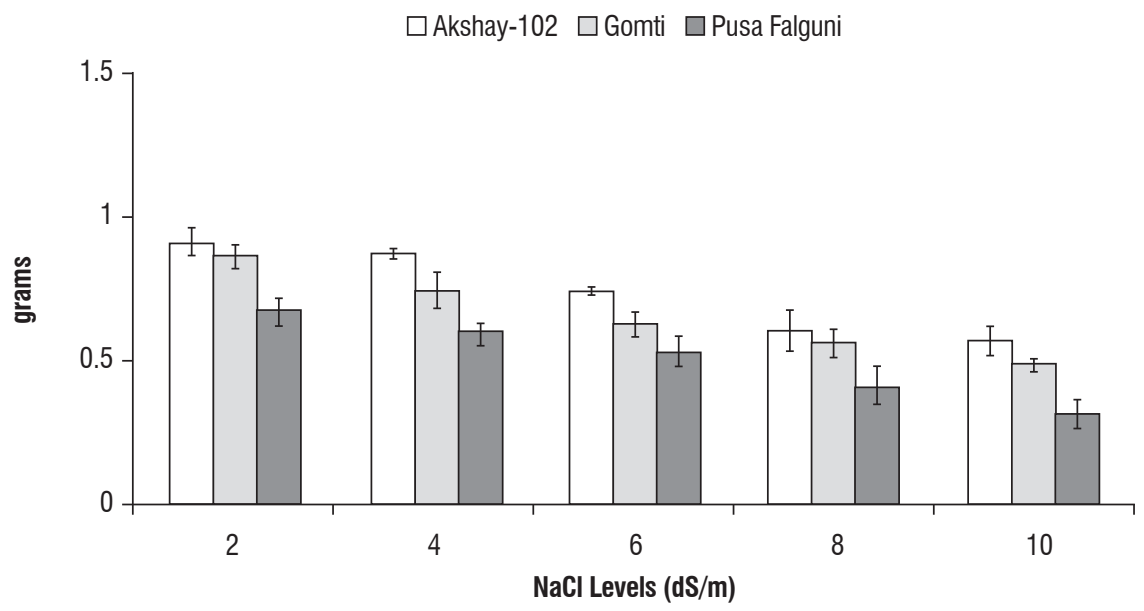

Figure 4. Variation in root dry weight of three cowpea cultivars under different NaCl levels $\left(2,4,6,8\right.$ and $\left.10 \mathrm{dS} \mathrm{m}^{-1}\right)$ after 40 days of seed sowing. The data are the mean $\pm S D(n=3) ; P<0.05$.

The $\mathrm{K}^{+}$contents in the leaves of Akshay-102 was higher than that in Gomti vu-89 and Pusa Falguni. With increase in the salinity level from 2 to $10 \mathrm{dS} \mathrm{m}^{-1}$ resulted decreases in $\mathrm{K}^{+}$concentration by 18,22 and $27 \%$ for Akshay-102, Gomti vu-89 and Pusa Falguni. Concentrations of $\mathrm{K}^{+}$at the higher salinity level were $25.33,24.18$, and $21.35 \mathrm{mg} \mathrm{g}^{-1}$ for Akshay-
102, Gomti vu-89 and Pusa Falguni, respectively (Table 1). At the $10 \mathrm{dS} \mathrm{m}^{-1}$ level of soil salinity, the concentration of $\mathrm{Na}^{+}$in the leaves of Akshay-102, Gomti vu-89 and Pusa Falguni increased 4.3, 3.6 and 3.5 fold, respectively (Table 1). The ratio of $\mathrm{K}^{+} / \mathrm{Na}^{+}$was influenced significantly by soil salinity level. High ratios of $\mathrm{K}^{+} / \mathrm{Na}^{+}$were found in Akshay- 
102 leaves than in Gomti vu-89 and Pusa Falguni leaves at all salinity levels (Table 1). Increase levels of soil salinity resulted in decreasing $\mathrm{K}^{+} / \mathrm{Na}^{+}$ratios. The $\mathrm{K}^{+}$content in plant tissues represents the main cation in plant cells, and is an important component of the cell osmotic potential (Reggiani et al., 1995).

Table 1. Accumulation of sodium, potassium content $\left(\mathrm{mg} \mathrm{g}^{-1}\right)$ and potassium/sodium ratio in leaf of three cowpea cultivars after 40 days of seed sowing under different salinity levels $\left(2,4,6,8\right.$ and $\left.10 \mathrm{dS} \mathrm{m}^{-1}\right)$.

\begin{tabular}{cccccccccc}
\hline \multicolumn{1}{c}{ Treatment } & \multicolumn{3}{c}{$\mathbf{N a}^{+}$} & & $\mathbf{K}^{+}$ & & $\mathbf{K}^{+} / \mathbf{N a}^{+}$ \\
\hline \multicolumn{1}{c}{ NaCl levels } & Akshay-102 & Gomti vu-89 & Pusa Falguni & Akshay-102 & Gomti vu-89 & Pusa Falguni & Akshay-102 & Gomti vu-89 Pusa Falguni \\
\hline $2 \mathrm{dSm}^{-1}$ & $1.94^{\mathrm{a}}$ & $2.43^{\mathrm{a}}$ & $2.56^{\mathrm{a}}$ & $32.3^{\mathrm{d}}$ & $31.14^{\mathrm{d}}$ & $29.43^{\mathrm{e}}$ & $16.64^{\mathrm{e}}$ & $12.81^{\mathrm{e}}$ & $1.49^{\mathrm{a}}$ \\
$4 \mathrm{dSm}^{-1}$ & $2.62^{\mathrm{b}}$ & $3.14^{\mathrm{b}}$ & $3.42^{\mathrm{b}}$ & $31.64^{\mathrm{d}}$ & $30.27^{\mathrm{d}}$ & $27.47^{\mathrm{d}}$ & $12.07^{\mathrm{d}}$ & $9.64^{\mathrm{d}}$ & $8.03^{\mathrm{e}}$ \\
$6 \mathrm{dSm}^{-1}$ & $4.43^{\mathrm{c}}$ & $4.84^{\mathrm{c}}$ & $5.04^{\mathrm{c}}$ & $29.28^{\mathrm{c}}$ & $28.15^{\mathrm{c}}$ & $25.5^{\mathrm{c}}$ & $6.61^{\mathrm{c}}$ & $5.81^{\mathrm{c}}$ & $5.06^{\mathrm{d}}$ \\
$8 \mathrm{dSm}^{-1}$ & $6.76^{\mathrm{d}}$ & $6.91^{\mathrm{d}}$ & $7.18^{\mathrm{d}}$ & $27.15^{\mathrm{b}}$ & $26.64^{\mathrm{b}}$ & $23.78^{\mathrm{b}}$ & $4.01^{\mathrm{b}}$ & $3.85^{\mathrm{b}}$ & $3.31^{\mathrm{c}}$ \\
$10 \mathrm{dSm}^{-1}$ & $8.35^{\mathrm{e}}$ & $8.75^{\mathrm{e}}$ & $8.98^{\mathrm{e}}$ & $25.33^{\mathrm{a}}$ & $24.18^{\mathrm{a}}$ & $21.35^{\mathrm{a}}$ & $3.03^{\mathrm{a}}$ & $2.76^{\mathrm{a}}$ & $2.4^{\mathrm{b}}$ \\
\hline
\end{tabular}

Values of means followed by different alphabets are statistically significant according to Duncan's multiple range test (DMRT) at $5 \%$ level. $(n=3)$.

$\mathrm{Ca}^{2+}$ contents in leaf decreased with increased salinity levels ( 2 to $10 \mathrm{dS} \mathrm{m}^{-1}$ ) by 22, 26 and $29 \%$ for Akshay-102, Gomti vu-89 and Pusa Falguni, respectively (Table 2). Essa (2002) reported that the main response of the plant to salt stress is a change in $\mathrm{Ca}^{2+}$ homeostasis and attributed that the salt tolerance of plants is their ability to avoid $\mathrm{Na}^{+}$toxicity and to maintain $\mathrm{Ca}^{2+}$ and $\mathrm{K}^{+}$concentrations. Also $\mathrm{Na}^{+}$is said to maintain turgor but it is unable to substitute for specific functions of $\mathrm{Ca}^{2+}$ and $\mathrm{K}^{+}$. According to Ioneva (1988), increase in $\mathrm{Na}^{+}$contents, decrease in $\mathrm{K}^{+}$contents and $\mathrm{K}^{+}$/ $\mathrm{Na}^{+}$ratios in plant leaves can be attributed to the effect of competition between $\mathrm{Na}^{+}$and $\mathrm{K}^{+}$ions on the absorptive sites of the plant roots.

There was a substantial difference in $\mathrm{Cl}^{-}$content and rate of accumulation between cultivars with increasing salinity. Increasing the salinity level from 2 to $10 \mathrm{dS} \mathrm{m}^{-1}$ increased the $\mathrm{Cl}^{-}$concentrations in the leaf to the tune of 3.4, 3.9, and 4.1 fold for Akshay-102, Gomti vu-89 and Pusa Falguni, respectively (Table 2). It has been reported that salt-tolerant species maintain high concentrations of $\mathrm{Ca}^{2+}$ and $\mathrm{K}^{+}$and low concentrations of $\mathrm{Na}^{+}$and $\mathrm{Cl}^{-}$. Sodium is not considered an essential element for plants and plants accumulate $\mathrm{Na}^{+}$at the expense of $\mathrm{Ca}^{2+}$ and $\mathrm{K}^{+}$in saline conditions (Kuiper, 1984). According to Greenway and Munns (1980), the reduction in $\mathrm{K}^{+}$concentration could inhibit growth by reducing the capacity for osmotic adjustment and turgor maintenance or by adversely affecting metabolic functions.

Increasing level of salinity showed higher proline content in the leaf. With increasing salinity levels Akshay -102 cultivar measured 3.12 to $6.45 \mathrm{mg} \mathrm{g}^{-1}$ proline followed by Pusa Falguni measuring 2.72 to $6.23 \mathrm{mg} \mathrm{g}^{-1}$ proline and least amount was measured in Gomti vu-89 with 2.77 to $5.96 \mathrm{mg} \mathrm{g}^{-1}$ proline (Table 2). Higher proline was noticed at higher salinity levels coupled with higher $\mathrm{Na}^{+}$constitute the osmoregulating substances, which favours water uptake from saline medium, thereby enabling the plants to maintain its physiological activity. Higher amounts of proline noticed in cowpea helps them in turgor regulation and thus the physiological activity. Moreover, proline is also known to act as major reservoir of energy and nitrogen for utilization upon exposure to salinity (Tawfik, 2008).

Table 2. Amount of calcium, chloride and proline content $\left(\mathrm{mg} \mathrm{g}^{-1}\right)$ accumulated in leaf of three cowpea cultivars under different salinity levels (2, 4, 6, 8 and 10 $\mathrm{dS} \mathrm{m}^{-1}$ ) after 40 days of seed sowing.

\begin{tabular}{|c|c|c|c|c|c|c|c|c|c|}
\hline \multirow{2}{*}{$\begin{array}{c}\text { Treatment } \\
\mathrm{NaCl} \text { levels }\end{array}$} & \multicolumn{3}{|c|}{$\mathrm{Ca}^{2+}$} & \multicolumn{3}{|c|}{$\mathrm{Cl}^{-}$} & \multicolumn{3}{|c|}{ Proline } \\
\hline & Akshay-102 & Gomti vu-89 & Pusa Falguni & Akshay-102 & Gomti vu-89 & Pusa Falguni & Akshay-102 & Gomti vu-89 & Pusa Falguni \\
\hline $2 \mathrm{dSm}^{-1}$ & $4.12^{\mathrm{c}}$ & $4.46^{c}$ & $4.49^{e}$ & $1.58^{\mathrm{a}}$ & $1.48^{\mathrm{a}}$ & $1.52^{\mathrm{a}}$ & $3.12^{b}$ & $2.77^{\mathrm{a}}$ & $2.72^{\mathrm{a}}$ \\
\hline $4 \mathrm{dSm}^{-1}$ & $4.05^{c}$ & $4.15^{b}$ & $4.13^{d}$ & $2.76^{b}$ & $2.88^{b}$ & $2.81^{b}$ & $3.88^{b}$ & $3.06^{b}$ & $3.25^{b}$ \\
\hline $6 \mathrm{dSm}^{-1}$ & $3.86^{\mathrm{b}}$ & $3.97^{\mathrm{b}}$ & $3.87^{c}$ & $3.42^{\mathrm{c}}$ & $3.75^{c}$ & $3.89^{c}$ & $4.67^{c}$ & $3.75^{c}$ & $4.04^{c}$ \\
\hline $8 \mathrm{dSm}^{-1}$ & $3.52^{\mathrm{a}}$ & $3.64^{a}$ & $3.58^{b}$ & $4.68^{d}$ & $4.96^{d}$ & $5.24^{d}$ & $5.72^{d}$ & $4.84^{d}$ & $5.16^{d}$ \\
\hline $10 \mathrm{dSm}^{-1}$ & $3.21^{\mathrm{a}}$ & $3.31^{\mathrm{a}}$ & $3.18^{\mathrm{a}}$ & $5.36^{e}$ & $5.79^{\mathrm{e}}$ & $6.28^{\mathrm{e}}$ & $6.45^{\mathrm{e}}$ & $5.96^{\mathrm{e}}$ & $6.23^{e}$ \\
\hline
\end{tabular}

Values of means followed by different alphabets are statistically significant according to Duncan's multiple range test (DMRT) at $5 \%$ level. $(n=3)$. 
Moreover, the tolerance differences between the cultivars are better reveled at the lowest levels of salt stress, as noticed in the measurement of $\mathrm{K}^{+} / \mathrm{Na}^{+}$and proline content. In general, this study suggested that Akshay-102 is the most tolerant cultivar and this tolerance is mainly due to the genetic variability among the seeds of each cultivar that may account for this phenomenon. The preset study confirms that at all salinity levels the variation in germination, plant growth, dry matter accumulation, ionic content and proline levels could be better explored in determining the tolerance capacity of the cowpea cultivars. In view of its better ion uptake and higher salt tolerance the Akshay-102 cultivar can be used as a salt tolerant cultivar.

Thus, the salt tolerance of all three Indian cvs studied are quite similar, despite of the higher performance exhibited by the cr Akshay-102. Comparisons of the tolerance features demonstrated by these cvs in relation to the characterization of other cvs described by Bernardo et al., (2006) highlights the relevance of germination capacity, $\mathrm{K}^{+} / \mathrm{Na}^{+}$ratio and proline accumulation as important features to be explored in programs to select and/or develop tolerant cultivars, to make possible the utilization of waste saline water as well as the cultivation of vast areas of the tropical world affected by salinity.

\section{REFERENCES}

Allen GJ, Wyn Jones RG, Leigh RA (1995) Sodium transport measured in plasma membrane vesicles isolated from wheat genotypes with differing $\mathrm{K}^{+}$/ $\mathrm{Na}^{+}$discrimination traits. Plant Cell Envir. 18:105-115.

Baccio D, di Navari-Izzo F, Izzo R (2004) Seawater irrigation antioxidant defense responses in leaves and roots of a sunflower (Helianthus annuus $L$ ) genotype. J. Plant Physiol. 161(12):1359-1366.

Baldwin AH, McKee KL, Mendelssohn IA (1996) The influence of vegetation salinity and inundation on seed banks of oligohaline coastal marshes. Amer. J. Bot. 83:470-479.

Bates LS, Waldren RP, Teare ID (1973) Rapid determination of free proline for water stress studies. Plant \& Soil. 39: 205-207.

Bernardo Murillo-Amador, Enrique Troyo-Dieguez, Jose Luis Garcia-ernandez, Raul Lopez-Aguilar, Narciso Ysac Avila-Serrano, Sergio Zamora-Salgado, Edgar Omar Rueda-Puente, Cengiz Kaya (2006) Effect of NaCl salinity in the genotypic variation of cowpea (Vigna unguiculata) during early vegetative growth. Sci. Horti. 108:423-432.

Bliss Cl (1967) Statistical methods for research in the natural sciences, Statistics in biology, McGraw Hill Book Company.

Chanyou Chen, Chengxue Tao, Hai Peng, Yi Ding (2007) Genetic analysis of salt stress responses in asparagus bean (Vigna unguiculata (L.) ssp. sesquipedalis Verdc.). J. Hered. 98(7):655-665.

Chapman VJ (1975) The salinity problem in general, its importance and distribution with special reference to natural halophytes. In: A. Poljakoff-
Mayber, and J. Gale (eds), Plants in Saline Environments, Springer-Verlag, New York. pp. 7-21.

Cramer GR (1992) Kinetics of maize leaf elongation. 2. Response of a Naexcluding cultivar and a $\mathrm{Na}$-including cultivar to varying $\mathrm{Na} / \mathrm{Ca}$ salinities. J. Exp. Bot. 43:857-864.

Epstein E, Norlyn JD, Rush DW, Kings RW, Kelly DB, Cunningham DB, Worna AF (1980) Saline culture of crops. A general approach. Science 210:399404.

Essa TA (2002) Effect if saline stress on growth and nutrient composition of three soybean (Glycine Max. L. Merrill) cultivers. J. Agro. Crop Sci. 188:8693.

Gururaja Rao G, Patel Prakash R, Bagdi DL, Chinchmalatpure Anil R, Nayak AK, Khandelwal MK, Meena RL (2005) Effect of saline water irrigation on growth ion content and forage yield of halophytic grasses grown on saline black soil. Indian J. Plant Physiol. 10(4):315-321.

Greenway H, Munns R (1980) Mechanism of salt tolerance in halophytes. Annu. Rev. Plant Physiol. 31:149-190.

Grieve CM, Suarez DL (1997) Purslane (Portulaca oleracea L.): a halophytic crop for drainage water reuse systems. Plant Soil. 192:277-283.

Hussein MM, Balbaa LK, Gaballah MS (2007) Developing a Salt Tolerant Cowpea Using Alpha Tocopherol. J. App. Sci. Research 3(10):1234-1239.

Ioneva ZS (1988) Effect of potassium ion $\mathrm{Na}+$ uptake by plants in conditions of chloride salinity. Fiziolo. Rasten. 14:42-47.

Jamal SN, Zafar lqbal M, Athar M (2006) Effect of aluminum and chromium on the germination and growth of two Vigna species. Int. J. Environ. Sci. Tech. 3:53-58.

Kuiper PJC (1984) Function of plant cell membranes under saline conditions: membrane lipid composition and ATPases. In: R. C. Staples, and G. H. Toenniesses (eds), Salinity Tolerance in Plants, Wiley-Interscience, New York. pp. 77-91.

Mariko S, Kachi N, Ishikawa S, Furukawa A (1992) Germination ecology of coastal plants in relation to salt environment. Ecological Res. 7:225-233.

Munns R, Termaat A (1986) Whole-plant responses to salinity. Aust. J. Plant Physiol. 13:143-160.

Nabil M, Coudret A (1995) Effects of sodium chloride on growth, tissue elasticity and solute adjustment in two Acacia nilotica subspecies. Physiologia Plantarum 93:217-224.

Norlyn JD, Epstein E (1984) Variability in salt tolerance of four triticale lines at germination and emergence. Crop Sci. 24:1090-1992.

Patel Kajal G, Ramana Rao TV (2007) Effect of simulated water stress on the physiology of leaf senescence in three genotypes of cowpea (Vigna unguiculata (L.) Walp). Indian J. Plant Physiol. 12(2):138-145.

Plaut Z, Grieve CM, Federman E (1989) Salinity Effects on Photosynthesis in Isolated Mesophyll Cells of Cowpea Leaves. Plant Physiol. 91:493-499.

Reggiani R, Bonzo S, Bertani A (1995) The effect of salinity on early seedling growth of seeds of three wheat (Triticum aestivum L.) cultivars. Can. J. Plant Sci. 75:175-177.

Rehman S, Harris PJC, Bourne WF, Wilkin J (1996) The effect of sodium chloride on germination and the potassium and calcium contents of acacia seeds. Seed Sci. Technol. 25:45-57.

Richards LA (1954) Diagnosis and improvement of saline and alkaline soils. USDA Agric. Handbook, Vol. 66, U.S. Department of Agriculture.

Tawfik KM (2008) Evaluating the Use of Rhizobacterin on Cowpea Plants Grown under Salt Stress. Res. J. Agri. Biol. Sci. 4(1):26-33.

Ungar IA (1996) Effect of salinity on seed germination, growth, and ion accumulation of Atriplex patula (Chenopodiaceae). Am. J. Bot. 83:604-607.

Zhu JK (2001) Plant salt tolerance. Trends Plant Sci. 6:66-71. 